\title{
INTEGRASI, PENGARUH DAN MASA DEPAN SISTEM CERDAS DALAM SISTEM PENDUKUNG MANAJEMEN
}

(Integration, Influence and The Future of Intelegence System in Management Support System)

\author{
Vensy Vydia, Nursanti Irliana \\ Program Studi Sistem Informasi, Jurusan Teknologi Informasi \\ Fakultas Teknologi Informasi dan Komunikasi \\ Email: vensy@usm.ac.id, santi@usm.ac.id
}

\begin{abstract}
Abstrak
Building a Management Support System is the first phase to support decision making and problem solving. More importantly, this system has to be introducedinto the organization and has to be used in accordance with the organization's goals. It that the integration of computer-based systems means the principal part of the system which function as a single integrated entity and can be done at the level of system-level development or application. Feedback from these matter is applied processing of data, knowledge and decision making model in increasing the use of today and the future.
\end{abstract}

Keywords : Integrated, Management Support System

\section{PENDAHULUAN}

Menambahkan kecerdasan pada proses pemodelan (membangun model atau menggunakan model yang sudah ada) dan pada manajemennya memberi banyak arti, karena beberapa tugas yang terlibat (misalnya, pemodelan dan pemilihan model) membutuhkan sejumlah keahlian. Topik pemodelan cerdas dan manajemen model cerdas menarik perhatian yang sangat besar dari kaum akademik yang dimulai pada era tahun 1990-an. Walau dalam implementasinya, integrasi tersebut cukup sulit dan lambat, misalnya Web Services, dapat memecahkan banyak masalah integrasi ditinjau dari studi detail mengenai lingkungan pemodelan berbasis komputer oleh pembuat model (analis) dan pengguna model (pengambil keputusan). Sebagian besar integrasi sistem pendukung manajemen saat ini dilakukan berbasis Web dan melibatkan sistem perusahaan, seperti Enterprise Management System, data warehouse, dan sistem cerdas. Salah satu perangkat lunak yang disediakan antara lain adalah Oracle, yang memasukkan optimalisasi sistem pendukung manajemen untuk penjadwalan dan alokasi sumber daya.

Sistem pendukung manajemen adalah bagian penting dalam revolusi informasi, web dan pengetahuan yang menjelma menjadi sebuah transformasi budaya yang disadari oleh banyak pihak dalam manajemen. Yang menjadi bagian dari transformasi cepat ini adalah masalah manajerial dan sosial : pengaruh pada struktur organisasional, daya tahan terhadap perubahan, tingkat pengangguran yang bertambah dengan cepat. Memisahkan Sistem Pendukung Manajemen dari sistem komputerisasi adalah tugas yang sulit, terutama karena tren integrasi pada sistem informasi lainnya yang berbasis komputer. Mengapa perlunya melakukan integrasi dalam perangkat lunak sistem pendukung manajemen : (1) untuk meningkatkan kemampuan aplikasi dari sistem pendukung manajemen, dalam hal ini piranti saling melengkapi. (2) meningkatkan kemampuan aplikasi nonsistem pendukung manajemen, misalnya 
piranti sistem cerdas ditambahkan dalam sistem analisa. (3) peningkatan kemampuan sistem cerdas, dalam hal ini adalah meningkatkan akuisisi pada sistem cerdas.

Sistem Pendukung Manajemen dapat memberikan implikasi mikro dan makro, mempengaruhi sebagian individu dan pekerjaan, struktur kerja departemen dan unit dalam suatu organisasi.

\section{PEMBAHASAN}

\subsection{Integrasi Sistem Cerdas Dalam Sistem Pendukung Manajemen}

Integrasi merupakan penyatuan bagianbagian dari sebuah sistem untuk tujuan tertentu. Integrasi dapat dilihat dari dua aspek, yaitu fungsional dan fisik.

Integrasi fungsional mengimplikasikan bahwa aplikasi-aplikasi yang berbeda disediakan sebagai sistem tunggal. Sebagai contoh, bekerja dengan electronic mail, menggunakan spreadsheet, berkomunikasi dengan database eksternal, membuat representasi grafis dan menyimpan serta memanipulasi data, semuanya dapat dilakukan pada workstation yang sama.

Integrasi Fisik mengacu pada pemaketan perangkat keras, perangkat lunak dan fitur komunikasi untuk mencapai integrasi fungsional. Adapun tiga tujuan utama integrasi perangkat lunak sistem pendukung manajemen :
- Meningkatkan kemampuan aplikasi sistem pendukung manajemen

Dalam hal ini peranti tersebut saling melengkapi. Setiap piranti menjalankan subtugas, misalnya sistem pendukung keputusan dapat digunakan untuk rekomendasi rencana alokasi sumber daya. Sehingga diharapkan untuk dapat diintegrasikan pada beberapa aplikasi sistem pendukung manajemen lainnya.

- Meningkatkan kemampuan aplikasi non sistem pendukung manajemen

Misalnya piranti kecerdasan bisnis ditambahkan ke sistem Enterprise Resources Planning (ERP) untuk menyediakan kemampuan analitik. Demikian juga, sistem cerdas ditambahkan dalam sebuah sistem forecasting atau sistem pelelangan elektronik.

- Peningkatan dengan piranti cerdas

Disini tujuan integrasi adalah untuk meningkatkan piranti lain. Pada level tertentu, alasan utama mengintegrasikan sistem pendukung keputusan dan sistem cerdas adalah manfaat dari masingmasing terknologi tersebut disediakan untuk yang lain.

Berikut ilustrasi dari integrasi Sistem Cerdas ke semua komponen sistem pendukung manajemen

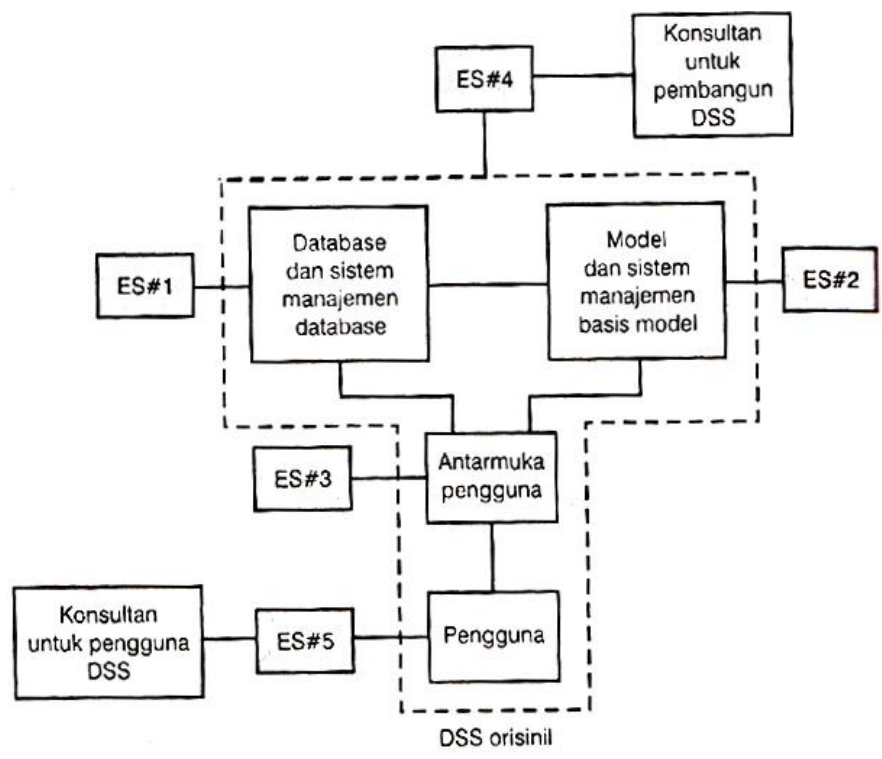

Gambar 1. Integrasi sistem Cerdas ke semua komponen Sistem Pendukung Manajemen 
Penjelasan dari ilustrasi Gambar 1 :

Sistem pakar dapat diintegrasikan ke dalam setiap atau semua komponen sistem pendukung manajemen. Seperti nampak dalam ilustrasi tersebut, ada lima sistem pakar :

- ES 1 : Komponen cerdas database

- ES 2 : Sistem Cerdas untuk basis model dan manajemennya

- ES 3 : Sistem untuk memperbaiki antarmuka pengguna

- ES 4 : Konsultan untuk pembuat sistem pendukung manajemen.

- ES 5: Konsultas untuk pengguna. Pengguna sistem pendukung manajemen membutuhkan saran pakar untuk persoalan yang kompleks, seperti sifat masalah, kondisi lingkungan atau masalah implementasi.

\subsection{Contoh Implementasi Sistem Cerdas Dalam Sistem Pendukung Manajemen}

Salah satu contoh implementasi sistem cerdas dalam sistem pendukung manajemen adalah sistem untuk mendukung pelayanan kesehatan bagi para orang lanjut usia (lansia) yang menghuni panti perawatan lansia. Sebuah sistem yang terkomputerisasi akan meminnta inputan kepada perawat mengenai kondisi dari pasien-pasien secara umum maupun khusus. Hasil dari inputan tersebut, adalah keputusan menentukan pengawasan dan perawatan seperti apa yang dibutuhkan oleh masing-masing pasien.

Hasil yang dikumpulkan oleh perangkat pengawas diinterpretasikan oleh sistem cerdas sehingga memungkinkan staff untuk menentukan :

- Lokasi pasien; mengindikasikan apakah penghuni berada dalam area fasilitas yang sesuai

- Penurunan berat badan; mengindikasikan kondisi-kondisi seperti gagal jantung
- Kegelisahan dimalam hari; mengindikasikan kondisi seperti obat penghilang rasa sakit yang tidak cukup

- Frekuensi ke kamar mandi; mengindikasikan persoalan medis seperti infeksi

- Lamanya pasien meninggalkan tempat tidur; mengindikasikan bahwa pasien mungkin jatuh atau melemah kondisinya

\subsection{Pengaruh Integrasi Sistem Cerdas Dalam Sistem Pendukung Manajemen}

Beberapa pengaruh integrasi sistem cerdas dalam sistem pendukung manajemen adalah sebagai berikut :

- Sistem cerdas akan berpengaruh pada efisiensi biaya personalia, karena pekerjaan "berpikir" yang seharusnya dikerjakan oleh manusia akan dikerjakan oleh sistem

- Kemudahan dalam mendapatkan keputusan melalui sebuah sistem yang terkomputerisasi akan mengubah pola hidup dan bekerja, yaitu beralih ke komunitas virtual

- Sistem cerdas yang diaplikasikan dalam berbagai kebutuhan pekerjaan akan mengurangi atau bahkan mengeliminasi kebutuhan kehadiran manusia. Hal ini dapat menghindarkan manusia dari lingkungan berbahaya atau tidak nyaman.

- Dengan adanya penerapan teknologi yang canggih, akan meningkatkan kepercayaan dan loyalitas konsumen kepada perusahaan terkait.

- Jika tidak dikelola dengan baik dan diberika $n$ batasan-batasan penggunaannya, makan akan muncul fenomena "menyalahkan komputer" demi menutupi kesalahan atau kekeliruan manusia. Untuk membenarkan tindakan yang seharusnya tidak benar. 


\subsection{Masa Depan Sistem Pendukung Manajemen}

Ada banyak pertanyaan yang muncul dalam kajian ini (1) apakah sistem cerdas telah matang dan sistem tersebut bisa dikatakan sebagai mainstream bidang teknologi informasi? (2) apakah sistem cerdas tersebut masih berkembang? Ada beberapa pandangan yang akan menjawab bagaimana masa depan sistem pendukung manajemen :

- Sistem pendukung manajemen menjadi teknologi berbasis web, dimana dilihat dari peningkatan penggunaan Web sebagai sarana pengembangan strategi pemasaran.

- Sistem cerdas yang diintegrasikan dengan sistem analitikal berbasis Web.

- Munculnya sistem cerdas jaringan syaraf dan fuzzy logic

- Teknologi dukungan keputusan frontline yang sebagian besar mendukung manajemen hubungan pelanggan dengan organisasi.

Berikut ilustrasi dari Sistem Pendukung Manajemen yang terintegrasi secara global.

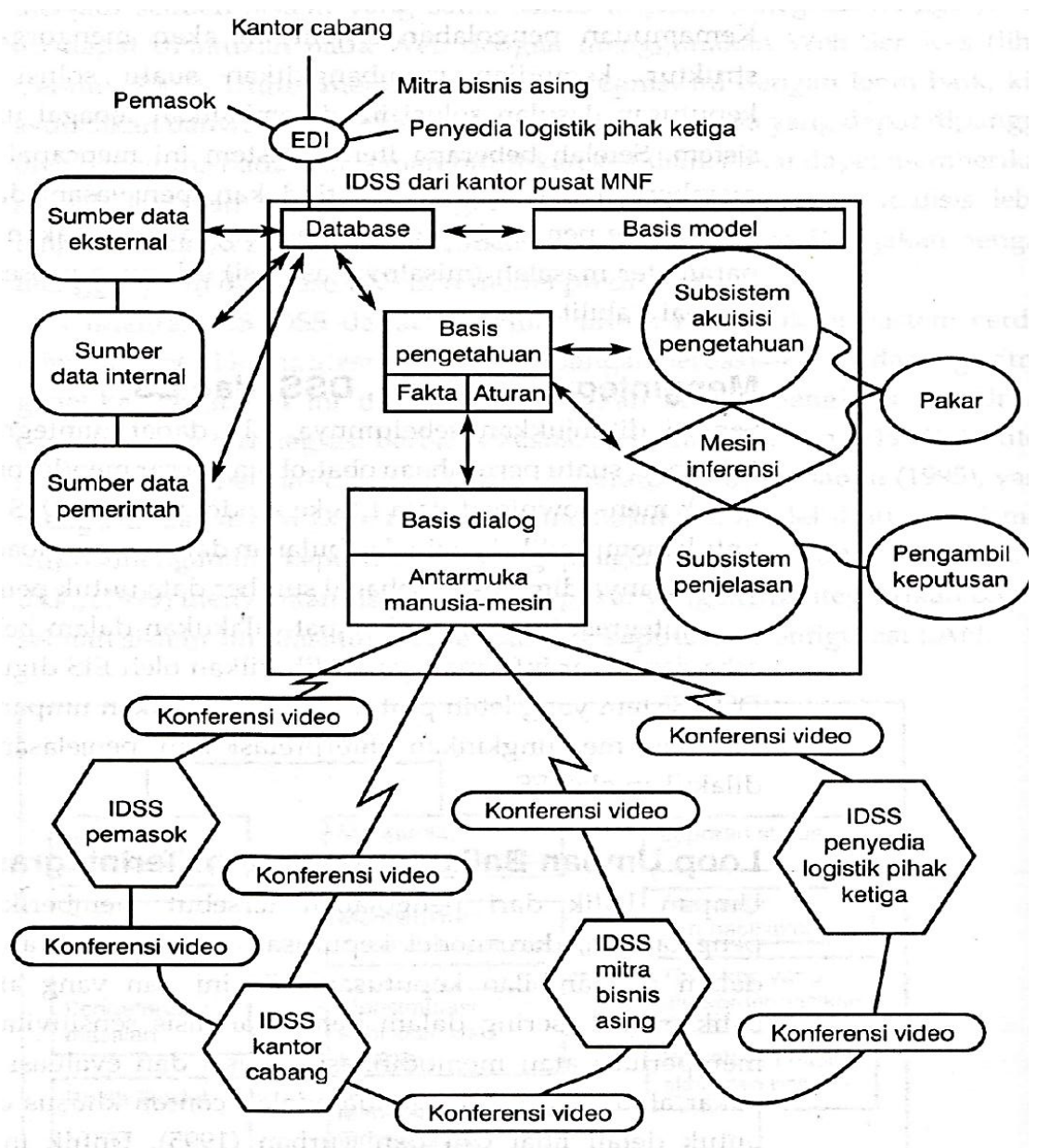

Gambar 2. Sistem Pendukung Manajemen yang terintegrasi secara global.

\section{KESIMPULAN}

Sistem pendukung manajemen memiliki pengaruh yang luas terhadap organisasi dan masyarakat. Pengaruh ini dimulai dari penyediaan akses informasi cepat sampai (komunikasi instan) di seluruh dunia, sampai sistem cerdas tiruan untuk menggantikan usaha manusia. Oleh karena itu, manajer perlu merencanakan sistem pendukung manajemen dimasa mendatang. 


\section{DAFTAR PUSTAKA}

Turban, E., et al. (2001). Information Technology for Management, $2^{\text {nd }}$ rev. ed. New York: John Willey.

Turban, E., et al. (2009). Decision Support Systems and Intelligent Systems, $7^{\text {th }}$ rev. ed. Yogyakarta: Andi. (2006). Sistem Informasi Dalam Berbagai Perspektif, 1 st ed. Informatika Bandung.

Lauden, Lauden. (2006). Sistem Informasi Manajemen : Mengelola Perusahaan Digital, $8^{\text {th }}$ rev. ed. Yogyakarta: Andi. 